\section{Evaluating the Effect of Chlorpheniramine on Patch Test Reactions amongst Eczema Patients Sensitised to Nickel}

\author{
SHAFINAZ S1 , ADAWIYAH J ${ }^{2}$, CHAN LC ${ }^{3}$, NORAZIRAH MN ${ }^{4}$ \\ ${ }^{1}$ Department of Dermatology, ${ }^{3}$ Department of Dermatology, Pulau Pinang Hospital, \\ Georgetown, 10990 Pulau Pinang, Malaysia. \\ ${ }^{2}$ Department of Medicine, ${ }^{4}$ Department of Medicine, Faculty of Medicine, Universiti \\ Kebangsaan Malaysia Medical Centre, Jalan Yaacob Latif, Bandar Tun Razak, 56000 \\ Cheras, Kuala Lumpur, Malaysia.
}

\begin{abstract}
ABSTRAK
Pemberhentian antihistamin untuk ujian tampalan (PT) dalam dermatitis alahan sentuhan (ACD) adalah lebih bersifat konvensional berbanding berasaskan bukti. Data menunjukkan bahawa antihistamin tanpa kesan mengantuk tidak mengganggu PT. Kajian ke atas kesan antihistamin tanpa kesan mengantuk adalah lebih relevan kerana ianya disyorkan untuk ekzema. Dalam kajian ini kami menentukan kesan chlorpheniramine pada PT, menentukan prevalens sensitif terhadap nikel dan alergen yang lazim. Kajian kohort label terbuka dijalankan di dua klinik dermatologi. Pesakit yang berindikasi untuk PT menjalani protokol standard PT tanpa antihistamin. Pesakit sensitif nikel menjalani PT kedua sambil mengambil chlorpheniramine. PT dinilai menggunakan skor North American Contact Dermatitis Research Group (NACDRG). Kemerahan dan gejala gatal yang diukur dengan Mexameter dinilai menggunakan skor analog visual. Sejumlah 82 pesakit menyertai kajian ini, 28 (34.1\%) adalah sensitif nikel. Purata umur adalah $40 \pm 17.7$ tahun dengan 22 (26.8\%) orang lelaki, 60 (73.2\%) perempuan. Indikasi untuk PT termasuk disyaki ACD (57.3\%), ekzema tangan dan kaki (34.1\%) dan ekzema tahap teruk yang disyaki mengalami ACD (6.1\%). Alergen paling lazim adalah methyldibromog/utaronitrile (40.2\%) diikuti oleh nikel sulfat (34.1\%), kalium dikromat (29.3\%) dan formaldehid (24.4\%). Dua puluh tiga pesakit sensitif nikel menjalani PT kedua. Tidak ada perbezaan dalam skor NACDRG dengan Chlorpheniramine atau tanpa chlorpheniramine $(p=0.968)$. Gejala gatal telah dikurangkan sebanyak $1.39 \pm 2.9, p=0.031$ dengan chlorpheniramine. Tahap kemerahan adalah $611.46 \pm 21.59$ dengan chlorpheniramine berbanding 613.87 \pm 27.5 tanpa chlorpheniramine, $p=0.671$. Chlorpheniramine tidak menjejaskan PT berdasarkan skor klinikal dan objektif. la mempunyai manfaat dalam mengurangkan
\end{abstract}

Address for correspondence and reprint requests: Adawiyah Jamil. Department of Medicine, Faculty of Medicine, Universiti Kebangsaan Malaysia Medical Centre, Jalan Yaacob Latif, Bandar Tun Razak, 56000 Cheras, Kuala Lumpur, Malaysia. Tel: +603-91456074 E-mail: adda_jamil@yahoo.com 
gatal disebabkan oleh PT.

Kata kunci: antihistamin, dermatitis alahan sentuhan, ujian patch

\begin{abstract}
Discontinuing antihistamines for patch testing (PT) in allergic contact dermatitis (ACD) is more conventional than evidence based. Data suggests that non-sedating antihistamines do not interfere with PT. Investigating the effects of sedating antihistamines are more relevant as these are recommended for eczema. We aimed to evaluate the effect of chlorpheniramine on PT, to determine the prevalence of nickel sensitization and common sensitizing allergens. An open labeled cohort study was conducted at two dermatology clinics. Patients indicated for PT underwent standard protocol where antihistamines were discontinued. Patients sensitised to nickel were subjected to a second nickel PT while taking chlorpheniramine. Results were evaluated using the North American Contact Dermatitis Research Group (NACDRG) score, a Mexameter measured erythema and pruritus was assessed using a visual analogue score. A total 82 patients were recruited, 28 (34.1\%) were sensitised to nickel. The mean age was $40 \pm 17.7$ years with $22(26.8 \%)$ males and 60 (73.2\%) females. Indications for PT included suspected ACD (57.3\%), hand and feet eczema (34.1\%) and severe eczema with suspected superimposed ACD (6.1\%). The commonest sensitizing allergens were methyldibromoglutaronitrile (40.2\%) nickel sulphate (34.1\%), potassium dichromate $(29.3 \%)$ and formaldehyde (24.4\%). A second PT was performed on 23 patients. There was no difference in the NACDRG score with chlorpheniramine or without chlorpheniramine $(p=0.968)$. Pruritus score was reduced by $1.39 \pm 2.9$, $\mathrm{p}=0.031$ with chlorpheniramine. The degree of erythema was $611.46 \pm 21.59$ with chlorpheniramine versus $613.87 \pm$ 27.5 without chlorpheniramine, $p=0.671$. Chlorpheniramine did not affect PT based on clinical and objective scorings. It has the additional benefit of reducing test-induced itch.
\end{abstract}

Keywords: allergic contact dermatitis, antihistamine, patch test

\section{INTRODUCTION}

Patch test (PT) is the gold standard test in investigating the allergen responsible for allergic contact dermatitis (ACD) (Fonacier et al. 2015). The test is designed to evaluate dermatitis caused by type IV hypersensitivity reaction. It is also used for investigation of contact urticaria caused by type I hypersensitivity reaction (Fonacier et al. 2015). First generation antihistamines are typically stopped 3 days before and during the test while second generation antihistamines are stopped at least 5 days before the test. In PT performed for suspected ACD, this practice is more conventional rather 
than evidence based. It could be a default practice derived from stopping antihistamine to avoid suppressing the PT reaction in contact urticaria. Histamine is not a key mediator in type IV hypersensitivity reaction thus a PT should not be affected by antihistamines.

A number of patients are not able to discontinue antihistamine for the test due to intolerable itch. This will delay institution of proper management especially allergen avoidence.We embarked on this study to clarify the effect of antihistamine on PT. Chlorpheniramine, a sedating anti histamine was chosen as it is more clinically relevant in patients with dermatitis (Arkwright et al. 2013). Nickel was the allergen chosen for this study as it is the most reproducible allergen on PT re-challenged (Memon \& Friedman 1996; Brasch et al. 1994).

\section{MATERIALS AND METHODS}

This was an open labeled cohort study conducted at the dermatology outpatient clinics in Universiti Kebangsaan Malaysia Medical Centre and Penang Hospital. The main objective was to evaluate the effect of chlorpheniramine on PT result. Secondary objectives were to determine the common allergens responsible for sensitization and to determine prevalence of nickel sensitization in patients with dermatitis. Inclusion criteria were patients with dermatitis with indication for PT and agreeable to undergo a second PT to nickel. Exclusion criteria included patients on systemic corticosteroid or systemic immunosuppressant 6 weeks prior to PT, patients with known severe reactions to PT, patients who has extensive eczema at the back, those who are allergic to chlorpheniramine or other components of the chlorpheniramine tablet and patients with arrhythmias or cardiac conduction problems. For the first PT, patients were required to stop antihistamine 5 days before the test and during the test. The patients were tested with our standard panel of 21 allergens plus other allergens which were clinically indicated. Patients who tested positive to nickel were subjected to the second PT conducted 6 weeks after the first test. Chlorpheniramine 4 mg nocte was taken for 5 days prior to, and continued throughout the duration of the test. Results of PT were assessed using the North American Contact Dermatitis Research Group (NACDRG) score and a mexameter was used for objective measurement of erythema on Day 3 and Day 5. Patients were asked to grade itch severity based on a visual analogue score of 0 to 10 on Day 5.

\section{RESULTS}

A total 82 patients were recruited, $28(34.1 \%)$ were sensitised to nickel. Mean age was $40 \pm 17.7$ years. There were $22(26.8 \%)$ males and $60(73.2 \%)$ females. The majority of patients were Malays 64 (78\%), 14 (17.1\%) were Chinese, 3 (3.7) were Indian and 1 $(1.2 \%)$ Nigerian. About half of the patients had no personal or family history of atopy, 51 (62.2\%), 13 (16.1\%) had asthma, another 13 (16.1\%) had 
allergic rhinitis, while 29 (35.5\%) patients had more than one atopic disease. Indications for PT included suspected ACD (57.3\%), hand and feet eczema (34.1\%) and severe eczema with suspected superimposed ACD (6.1\%) (Table 1). The most common sensitizing allergens were methyldibromoglutaronitrile (MDGN) $(40.2 \%)$ followed by nickel sulphate $(34.1 \%)$, potassium dichromate (29.3\%), cobalt chloride (28.0\%), formaldehyde (24.4\%), neomycin sulphate $(18.3 \%)$ and tixocortal-21pivalate $(15.9 \%)$ (Table 2$)$. Twenty-three patients who were sensitised to nickel underwent a second PT. There was no difference in the NACDRG score for PT with chlorpheniramine or without chlorpheniramine $(p=0.968)$. Pruritus score was reduced by $1.391 \pm 2.9$, $\mathrm{p}=0.031$ with chlorpheniramine. The degree of erythema was $611.46 \pm 21.59$ with chlorpheniramine versus 613.87 \pm 27.5 without chlorpheniramine, the difference was not statistically significant, $p=0.671$ (Table 3).

\section{DISCUSSION}

MDGN was the most common sensitizer in our patients. MDGN is a preservative commonly found in cosmetics, toiletries, detergents, paints and adhesives. In Europe, sensitization rate for MDGN increased from $0.7 \%$ to $4.6 \%$ from 1991 to 2009 , leading to its ban (Yim et al. 2014). The Malaysian National Pharmaceutical Regulatory Agency banned MDGN use in cosmetic products since 2007. However, MDGN was still reported as the fourth common preservative sensitizer
Table 1: Characteristics of the study population

\begin{tabular}{|c|c|}
\hline Characteristics & $\begin{array}{c}\mathrm{n}(\%) \text { or Median } \\
\mathrm{N}=82\end{array}$ \\
\hline Median age, years & $40(6-81)$ \\
\hline \multicolumn{2}{|l|}{ Gender } \\
\hline Male & $22(26.8)$ \\
\hline Female & $60(73.2)$ \\
\hline \multicolumn{2}{|l|}{ Ethnicity } \\
\hline Malay & $64(78.0)$ \\
\hline Chinese & $14(17.1)$ \\
\hline Indian & $3(3.7)$ \\
\hline Others & $1(1.2)$ \\
\hline \multicolumn{2}{|l|}{ History of atopy } \\
\hline Asthma & $13(16.1)$ \\
\hline Allergic rhinitis & $13(16.1)$ \\
\hline Dermatitis & $10(32.3)$ \\
\hline$>1$ atopy & $11(35.5)$ \\
\hline \multicolumn{2}{|l|}{ Indications for PT } \\
\hline Suspected ACD & $47(57.3 \%)$ \\
\hline Hand and feet dermatitis & $28(34.1 \%)$ \\
\hline $\begin{array}{l}\text { Severe dermatitis, } \\
\text { suspected superimposed } \\
\text { ACD }\end{array}$ & $5(6.1 \%)$ \\
\hline
\end{tabular}

Table 2: Common sensitizing allergens in the study population

\begin{tabular}{lc}
\hline Allergen & $\begin{array}{c}\text { Positive PT } \\
\mathbf{n}(\%)\end{array}$ \\
\hline Methyldibromoglutaronitrile & $33(40.2)$ \\
Nickel sulphate & $28(34.1)$ \\
Potassium dichromate & $24(29.3)$ \\
Cobalt chloride & $23(28.0)$ \\
Formaldehyde & $20(24.4)$ \\
Neomycin sulphate & $15(18.3)$ \\
Tixocortal-21-pivalate & $13(15.9)$ \\
4-phenylenidiamine base & $11(13.0)$ \\
Fragrance mix & $11(13.0)$ \\
Cl-me-isothiazolinone & $11(13.0)$ \\
Balsam of Peru & $10(12.2)$ \\
Linolin & $10(12.2)$ \\
\hline
\end{tabular}


Table 3: PT results and itch score without and with chlopheniramine

\begin{tabular}{lcccc}
\hline & $\begin{array}{c}\text { Patch test without } \\
\text { chlorpheniramine }\end{array}$ & $\begin{array}{c}\text { Patch test with } \\
\text { chlorpheniramine }\end{array}$ & Mean difference & p value \\
\hline $\begin{array}{l}\text { NACDRG score } \\
\text { (median, tertiles) }\end{array}$ & $2.5(2.0-4.0)$ & $2.5(1.5-4.0)$ & 0 & 0.968 \\
$\begin{array}{l}\text { Itch score } \\
\text { (mean } \pm \text { SD) }\end{array}$ & $5.35 \pm-2.49$ & $3.96 \pm 2.12$ & $1.391 \pm 2.90$ & 0.031 \\
$\begin{array}{l}\text { Mexameter reading } \\
\text { (mean } \pm \text { SD) }\end{array}$ & $613.87 \pm 27.5$ & $611.46 \pm 21.59$ & $2.41 \pm-26.8$ & 0.671 \\
\hline
\end{tabular}

after paraben mix, formaldehyde and methylchloroisothiazolinone (MCI)/ methylisothiazolinone (MI) in 2011 (Yee \& Rohana 2013). At our centre, MDGN is one of the top 5 sensitizers since 2011, in 2016 it is the most common sensitizing allergen among our patients. The sensitization rate in this study was much higher most likely due to continuous exposure among the population and widespread use of the chemical in cosmetics and toiletries. Nickel, potassium dichromate and cobalt chloride are common sensitizers worldwide including in our country (DeKoven et al. 2017; Leok et al. 1992; Akasya-Hillenbrand \& Ozkaya-Bayazit 2002; Rodrigues \& Goulart 2016).

First and second generation antihistamines are different in their central nervous system, anticholinergic, antiallergy and antiinflammatory effects (Canonica \& Blaiss 2011; Vena et al. 2008). First generation antihistamines are recommended as an adjunct in the treatment of itch caused by eczema due to its sedating effect (Arkwright et al. 2013). We found that chlorpheniramine, a first generation sedating antihistamine did not affect PT result based on both clinical and objective evaluations. The effect of second generation antihistamines on PT has been previously evaluated.
Clinical scores of PT were unchanged by cetirizine, loratadine and desloratadine (Grob et al. 1998; Chen et al. 2012; Li et al. 2011). Another study using the same loratadine dose showed reduction in both clinical and objective assessments, however the small sample size of this study may account for the difference observed in the results (Motolese et al. 1995).

Reduction in itch induced by PT is an additional benefit for patient undergoing PT. Patients would be more comfortable during the test. The probability of the patient scratching and handling the PT is reduced, thus contact between the allergen and the skin will not be compromised as this is a common factor that affects PT result.

\section{CONCLUSION}

Chlorpheniramine does not affect PT results and it may be continued throughout the test. Reducing PT induced itch is an additional benefit of using chlopheniramine during PT.

\section{REFERENCES}

Akasya-Hillenbrand, E., Ozkaya-Bayazit, E. 2002. Patch test results in 542 patients with suspected contact dermatitis in Turkey. Contact Dermatitis 46(1): 17-23.

Arkwright, P.D., Motala, C., Subramanian, H., 
Spergel, J., Schneider, L.C., Wollenberg, A 2013. Management of difficult to treat atopic dermatitis. J Allergy Clin Immunol Pract 1(2): 142-51.

Brasch, J., Henseler, T., Aberer, W., Bäuerle, G. Frosch, P.J., Fuchs, T., Fünfstück, V., Kaiser, G., Lischka, G.G., Pilz, B. 1994. Reproducibility of patch tests: a multicenter study of synchronous left versus right sided patch tests by the German Contact Dermatitis Research Group. J Am Acad Derm 31(4): 584-91.

Canonica, G.W., Blaiss, M. 2011. Antihistaminic, antiinflammatory, and antiallergic properties of the nonsedating second-generation antihistamine desloratadine: A review of the evidence. World Allergy Organ J 4(2): 47-53.

Chen, X.J., Chen, L.L., Shi, X., Xie, L.X., Leng, H., Ji, J., Lu, D.D. 2012. The effect of desloratadine on patch test reactions in Chinese patients. Asian Pac J Immuno/ 30(3): 209-13.

DeKoven, J.G., Warshaw, E.M., Belsito, D.V., Sasseville, D., Maibach, H.I., Taylor, J.S., Marks, J.G., Fowler, J.F., Mathias, C.G., DeLeo, V.A., Pratt, M.D., Zirwas, M.J., Zug, K.A. 2017. North American Contact Dermatitis Group Patch Test Results 2013-2014. Dermatitis 28(1): 33-46.

Fonacier, L., Bernstein, D.I., Pacheco, K., Holness, D.L., Blessing-Moore, J., Khan, D., Lang, D., Nicklas, R., Oppenheimer, J., Portnoy, J., Randolph, C., Schuller, D., Spector, S., Tilles, S., Wallace, D. 2015. Contact dermatitis: a practice parametere update 2015. J Allergy Clin Immunol Pract 3(3 Suppl): S1-S39.

Grob, J.J., Castelain, M., Richard, M.A., Bonniol, J.P., Beraud, V., Adhoute, H., Guillou, N., Bonerandi, J.J. 1998. Anti-inflammatory properties of cetirizine in a human contact dermatitis model. Clinical evaluation of patch test is not hampered by antihistamines. Acta Derm Venereol 78(3): 194-7.
Leok, J.T., Goh, C.L., Ng, S.K., Wong, W.K. 1992. Changing trends in the epidemiology of contact dermatitis in Singapore. Contact Dermatitis 26(5): 321-6.

Li, P., Sun, X.D., Shi, X., Cai, Y.L., Zhang, J., Chen, X.J., Chen, L.L., Xie, L.X. 2011. Influences on skin patch test reaction in Chinese due to Loratadine in conventional dose. Chin J Dermatol 11: 7657.

Memon, A.A., Friedman, P.S. 1996. Studies on the reproducibility of allergic contact dermatitis. $\mathrm{Br}$ J Dermato/ 134(2): 208-14.

Motolese, A., Ferdani, G., Manzini B.M., Seidenari, S. 1995. Echographic evaluation of patch test inhibition by oral antihistamine. Contact Dermatitis 32(4): 250-1.

Rodrigues, D.F., Goulart, E.M. 2016. Patch-test results in children and adolescents: systematic review of a 15-year period. An Bras Dermato/91(1): 6472.

Vena, G.A., Cassano, N., Buquicchio, R., Ventura, M.T. 2008. Antiinflammatory effects of H1antihistamines: clinical and immunological relevance. Curr Pharm Des 14(27): 2902-11.

Yee, V.S., Rohana, R. 2013. Patch testing with preservative sensitizers. A year retrospective study from Selayang Hospital. Malaysian J Derm 30; 1-6.

Yim, E., Baquerizo Nole, K.L., Tosti, A. 2014. Contact dermatitis caused by preservatives. Dermatitis 25(5): 215-31.

Received: 25 May 2017

Accepted: 23 Oct 2017 